\title{
THE EFFECT OF INTRALUMINALLY ADMINISTERED DRUGS ON IMPLANTATION IN NORMAL PREGNANT RATS
}

\author{
G. P. GARG AND R. R. CHAUDHURY* \\ Department of Pharmacology, \\ Postgraduate Institute of Medical Education and Research, \\ Chandigarh, India
}

(Received 17th Fune 1971)

It has been suggested that histamine released by an oestrogen surge at the time of implantation plays an important part in nidation of the fertilized ovum in the rat. These observations were based on findings by Shelesnyak and his coworkers that (a) administration of intraluminal histamine caused an induction of deciduomata, (b) intraluminal administration of histamine antagonists could inhibit deciduomata, (c) intraluminal administration of histamine antagonists could inhibit ovum implantation, and (d) systemic administration of histamine and histamine-releasing agents induced deciduomata (Shelesnyak 1952a, b, c, 1954; Kraicer \& Shelesnyak, 1958). These workers also observed a fall in the level of the histamine content of the uterus at the time of implantation. The results of other investigators have, however, not confirmed this hypothesis (Finn \& Keen, 1962; Wrenn, Bitman, Cecil \& Gilliam, 1964). Tachi, Tachi \& Lindner (1970) have also shown that intraluminal administration of pyrathiazine, promethazine and benadryl into the uterus of pseudopregnant rats at dose levels reported to suppress the decidual reaction caused extensive necrosis of the endometrium. The suppression of the decidual reaction could not, therefore, be attributed to the antihistaminic action of these drugs.

In this study, the possible rôle of histamine in implantation has been investigated by studying the effect of intraluminally administered drugs which release histamine, such as Compound $48 / 80$ and polymixin $\beta$ sulphate, antihistaminic drugs such as dimethindene maleate and pheniramine maleate, another pharmacologically active agent found in the uterus, 5 hydroxytryptamine, and the 5 hydroxytryptamine antagonistic drug, 1-methyl-d-lysergic acid butanolamide (ULM-491), on implantation in normal pregnant rats. These drugs were administered at different doses on Days 3 and 4 of pregnancy.

Adult female rats of proven fertility were left overnight with males and the presence of thick clumps of spermatozoa in the early morning vaginal smear was taken to indicate Day 1 of pregnancy. These females were then left in separate cages and on Day 3 or 4 of pregnancy, the rat was anaesthetized with ether and the uteri exposed. Intraluminal administration of the test drug was made into the uterine horn as described by Wrenn et al. (1964) with the modification that,

* Present address: World Health Organization, 1211 Geneva 27, Switzerland. 
whereas these investigators did not administer anything in the control horn, the same volume of normal saline, $0.05 \mathrm{ml}$ or $0.1 \mathrm{ml}$ according to the experiment, was administered by means of a No. 30 gauge needle with blunt point into the control horn. The animals were subjected to laparotomy on Day 10 of pregnancy to observe the number of implantation sites.

TABLE 1

THE EFFEGT OF INTRALUMINALLY ADMINISTERED DRUGS ON IMPLANTATION IN NORMAL PREGNANT RATS

\begin{tabular}{|c|c|c|c|c|c|}
\hline $\begin{array}{l}\text { Substance administered } \\
\text { intraluminally }\end{array}$ & $\begin{array}{l}\text { Dose } \\
(\mu g)\end{array}$ & $\begin{array}{l}\text { Day of } \\
\text { pregnancy of } \\
\text { recipient rats }\end{array}$ & $\begin{array}{c}\text { Mean no. of } \\
\text { sites on } 1 \\
\text { pregnan } \\
\text { Right horn } \\
\text { (control) }\end{array}$ & $\begin{array}{l}\text { implantation } \\
\text { ay } 10 \text { of } \\
y .5 \mathrm{D} \\
\text { Left horn } \\
\text { (treated })\end{array}$ & $\begin{array}{c}\text { Statistical } \\
\text { significance } \\
\quad(P)\end{array}$ \\
\hline $\begin{array}{l}\text { Compound } 48 / 8 \\
\text { Polymixin } \beta \text { sulphate } \\
\text { Polymixin } \beta \text { sulphate } \\
\text { Dimethindene maleate } \\
\text { Dimethindene maleate } \\
\text { Dimethindene maleate } \\
\text { Pheniramine maleate } \\
\text { Pheniramine maleate } \\
\text { Pheniramine maleate } \\
\text { 5-Hydroxytryptamine } \\
\text { 5-Hydroxytryptamine } \\
\text { 5-Hydroxytryptamine } \\
\text { 5-Hydroxytryptamine } \\
\text { Lysergic acid butanolamide } \\
\text { Lysergic acid butanolamide }\end{array}$ & $\begin{array}{r}10 \\
10 \\
10 \\
10 \\
10 \\
50 \\
10 \\
10 \\
20 \\
50 \\
200 \\
200 \\
200 \\
50 \\
50\end{array}$ & $\begin{array}{l}3 \\
3 \\
4 \\
3 \\
4 \\
3 \\
3 \\
4 \\
3 \\
4 \\
3 \\
4 \\
6 \\
3 \\
4\end{array}$ & $\begin{array}{l}4 \cdot 2 \pm 2 \cdot 8 \\
3 \cdot 5 \pm 2 \cdot 5 \\
3 \cdot 0 \pm 2 \cdot 2 \\
2 \cdot 8 \pm 2 \cdot 5 \\
5 \cdot 4 \pm 1 \cdot 8 \\
5 \cdot 2 \pm 2 \cdot 6 \\
3 \cdot 1 \pm 3 \cdot 0 \\
2 \cdot 4 \pm 2 \cdot 3 \\
2 \cdot 9 \pm 2 \cdot 4 \\
4 \cdot 4 \pm 1 \cdot 2 \\
5 \cdot 0 \pm 1 \cdot 5 \\
3 \cdot 0 \pm 3 \cdot 0 \\
2 \cdot 8 \pm 3 \cdot 3 \\
4 \cdot 6 \pm 1 \cdot 8 \\
2 \cdot 8 \pm 1 \cdot 9\end{array}$ & $\begin{array}{l}3 \cdot 4 \pm 2 \cdot 0 \\
3 \cdot 3 \pm 2 \cdot 49 \\
3 \cdot 4 \pm 2 \cdot 1 \\
3 \cdot 6 \pm 2 \cdot 1 \\
4 \cdot 8 \pm 2 \cdot 2 \\
3 \cdot 0 \pm 1 \cdot 5 \\
2 \cdot 5 \pm 2 \cdot 8 \\
1 \cdot 8 \pm 2 \cdot 0 \\
2 \cdot 5 \pm 1 \cdot 8 \\
2 \cdot 4 \pm 2 \cdot 0 \\
2 \cdot 4 \pm 1 \cdot 8 \\
2 \cdot 4 \pm 2 \cdot 5 \\
4 \cdot 2 \pm 2 \cdot 4 \\
4 \cdot 0 \pm 3 \cdot 0 \\
2 \cdot 0 \pm 2 \cdot 0\end{array}$ & $\begin{array}{l}>0.05 \\
>0.05 \\
>0.05 \\
>0.05 \\
>0.05 \\
>0.05 \\
>0.05 \\
>0.05 \\
>0.05 \\
>0.05 \\
>0.05 \\
>0.05 \\
>0.05 \\
>0.05 \\
>0.05\end{array}$ \\
\hline
\end{tabular}

Table 1 shows the substance and dose administered, and the number of implantation sites in both uterine horns on Day 10 of pregnancy. The results indicated clearly that, at the doses used, histamine-releasing agents, antihistaminic drugs, 5-hydroxytryptamine and the 5-hydroxytryptamine blocking agent administered intraluminally on Day 3 or 4 of pregnancy had no effect on subsequent implantation. The results do not provide any support for the hypothesis that histamine has any such rôle to play in the implantation of the fertilized ovum.

\section{REFERENCES}

Fins, C. A. \& KeEN, P. M. (1962) Failure of histamine to induce deciduomata in the rat. Nature, Lond. 194, 960 .

Kraicer, P. F. \& Shelesnyak, M. C. (1958) The induction of deciduomata in the pseudopregnant rat by systemic administration of histamine, and histamine releasers. F. Endocr. 17, 324.

Shelesnyak, M. C. (1952a) The inhibition of decidual cell reaction in the rat by local action of diphenhydramine (Benadryl). Bull. Res. Coun. Israel, 2, 74.

Shelesnyak, M. G. (1952b) Inhibition of decidual cell formation in the pseudopregnant rat by histamine antagonists. Am. F. Physiol. 170, 522.

Shelesnyak, M. C. (1952c) Inhibition of deciduomata formation by antihistamine agents. Bull. Res. Coun. Israel, 2, 202.

ShelesNyaK, M. C. (1954) Comparative effectiveness of antihistamine in suppression of the decidual cell reaction in the pseudopregnant rat. Endocrinology, 54, 396. 
TACHI, C., TACHI, S. \& Lindner, H. R. (1970) Action of antihistamines on the endometrium and the histamine theory of decidual induction. 7. Reprod. Fert. 23, 169.

Wrenn, T. R., Bitman, J., Cecil, H. C. \& Gilliam, D. R. (1964) Uterine deciduomata: role of histamine. F. Endocr. 28, 149. 